Editorial

\title{
City of Flows: The Need for Design-Led Research to Urban Metabolism
}

\author{
Rob Roggema ${ }^{1,2}$ \\ ${ }^{1}$ Office for Adaptive Planning and Design, Cittaideale, 6707 LC Wageningen, The Netherlands; E-Mail: rob@cittaideale.eu \\ 2 Knowledge Centre NoorderRuimte, Hanze University Groningen, 9747 AS Groningen, The Netherlands
}

Submitted: 22 January 2019 | Published: 21 February 2019

\begin{abstract}
The design of cities has long ignored the flows that shape the city. Water has been the most visible one, but energy and materials were invisible and/or taken for granted. A little over 50 years ago, Abel Wolman was the first to illuminate the role of water flows in the urban fabric. It has long been a search for quantitative data while the flows were mostly seen as separated entities. The fact they invisibly formed the way the city appears has been neglected for many years. In this thematic issue the "city of flows" is seen as a design task. It aims to bring to the fore the role flows can play to be consciously used to make spatial decisions in how and where certain uses and infrastructure is located. Efficient and sustainable.
\end{abstract}

\section{Keywords}

energy; food; food-energy-water nexus; nexus thinking; urban flows; urban metabolism; urban planning; water

\section{Issue}

This editorial is part of the issue "The City of Flows: Urban Planning of Environmental Flows", edited by Rob Roggema (Cittaideale, The Netherlands/Hanze University Groningen, The Netherlands).

(C) 2019 by the author; licensee Cogitatio (Lisbon, Portugal). This article is licensed under a Creative Commons Attribution 4.0 International License (CC BY).

\section{Introduction: Brief History of Urban Metabolism}

When we think about flows in the city the term urban metabolism is often used. Like our body, the city is seen as an organism which requires resources to function, and the way these resources are used to serve all different functions of the city, and to which waste flows this leads, determines the metabolism of the body, and translated to urban flows, the urban metabolism. The first to point at the role that a flow, in this case the flow of water, plays in the urban fabric was Abel Wolman. He calculated the size of the water flows that flew through the city and discussed how this flow could be managed more efficiently and more sustainable (Wolman, 1965). Some decades later the discussion about pollution of the urban environment led to the need to understand the urban pollutants better and their influence on the flows of the city. Air could be polluted and could pollute soils and water, polluted water could pollute food systems and have a profound impact on human health. It was therefore essential to develop understanding about how these flows in the city behaved, how big they were and how they influenced the quality of life, and how they produced waste streams in the form of pollution. An important insight was offered when urban flows became part of an ecological conceptual model (Van Leeuwen, 1981). In this model the aims for a sustainable management of flows in the city was established. In a so-called eco-device model (Figure 1) the incoming and outgoing flows were symbolized, as well as the flows that were prevented from entering the area or leaving. This way, an abstraction of the flows of water, energy and materials could be given, and determine if the system was performing ecologically well or not.

This abstract model has been modified and further elaborated in order to illustrate the flows in greater detail and also show the external factors of the system, such as climate change, that determine the context of the "extended urban metabolism model" (Newman, 1999). Though Peter Newman has put the model in practice, especially in traffic and mobility plans, working with the parameters in an integrated way to create a spatial perspective remained a challenge. Jón Kristinsson invented a three-dimensional model (Figure 2, left) in which, for every layer, the specific flows were symbolized as in or outgoing flows, which could re-enter the system at an- 

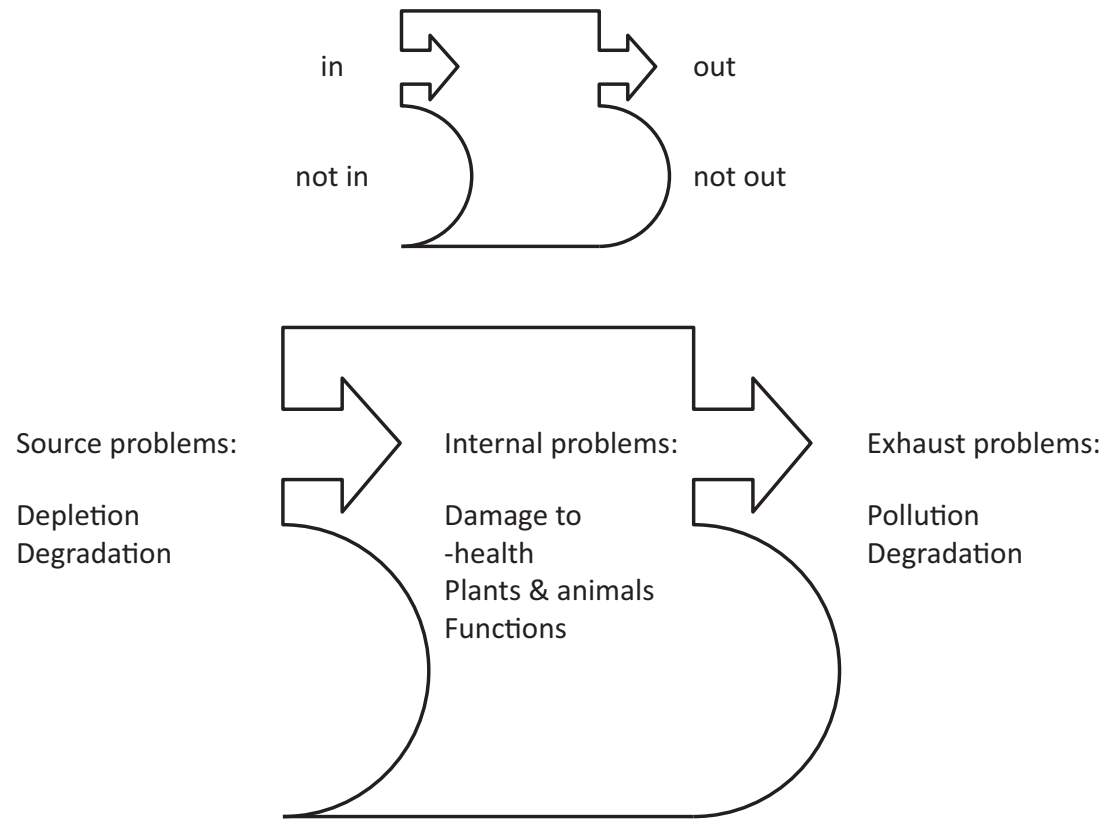

Figure 1. Eco-device model (IN-Not IN; OUT-not OUT). Source: After Van Leeuwen (1981).

other level. This way a comprehensive 3D-model of a city could be drawn, and the city seen as an ecosystem itself (Tomásek, 1979). The levels Kristinsson determined were the abiotic, biotic, urban and atmospheric layers (Kristinsson, 2012). Nowadays, more layers could and should be added to this systemic image (Figure 2, right), as demonstrated by van Timmeren and Henriquez (2015). The exchange of flows between more layers will open up the possibilities to close cycles and become a more sustainable urban ecosystem. A direct link can be established here with thinking that takes place around the theme of Smart Cities.
The ecosystem model is reduced to few levels (earth, city, networks) in the new model (new linkages and potentials to connect and exchange flows, materials, streams), and lacks the (a)biotic layers at all. When these would be integrated in the model a more comprehensive model would emerge, hence consist of the abiotic, biotic, user, interface, address, network, city, cloud and earth layers.

Where most of Kristinsson's (2012) work focuses on the building itself, trying to optimize the indoor climate and direct environment of the building using technological innovations that make use of the different available

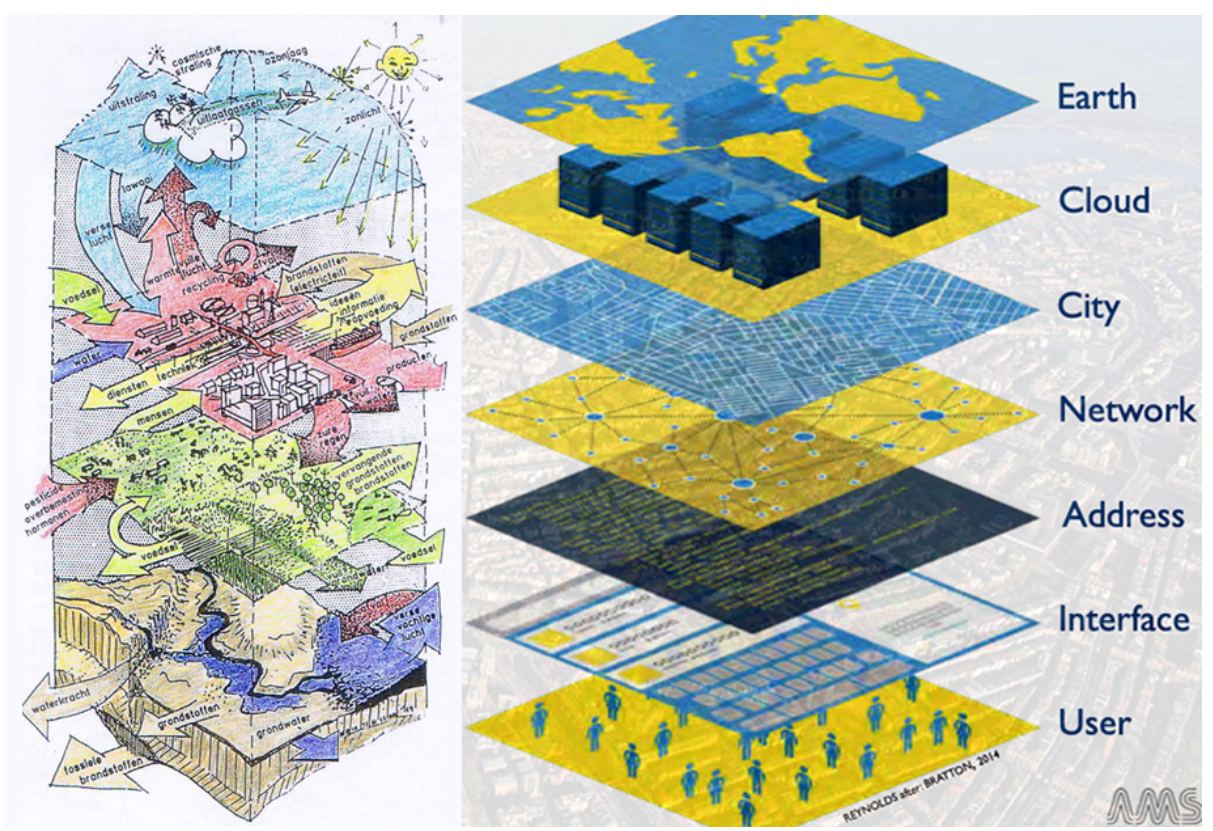

Figure 2. Kristinsson's (2012) 3D-model of the city as an ecosystem (left); van Timmeren and Henriquez' (2015) "the Stack" layers including recent digital additions (right). 
flows in the vicinity and aim to close resource and waste cycles as good as possible, "until the good (urban) traveler leaves no trace", at the scale of the city as a whole additional connections, exchange and gains can be harvested. In the Rotterdam Biennale 2014, curated by Dirk Sijmons, this has been investigated (Figure 3) under the title Urban by Nature (Brugmans \& Strien, 2014), and design-led projects have shown that large benefits can be by connecting the waste streams of certain flows to the resource demands of others at the regional urban scale (Gemeente Rotterdam, IABR, FABRIC, JCFO, \& TNO, 2014).

Overlooking 50-odd years of scientific research, thinking, academic education, designing and innovating around the topic of urban flows, several aspects presented themselves as key components. The quantification of urban flows, the ambition to close cycles and minimize waste flows, the systemic approach, and the implications for the spatial configuration of the city are recurring subjects. However, the dominance which could be expected of design-led approaches did not come to total fruition. At the end of the day urban flows must be quantified, in order to assess their performance and this seems the dominant paradigm. Instead of looking at the size of flows only, ore aspects require synergy, something that can be easily achieved through design. The synergies between livability, design, urban flows, assessment tools and sustainability has been extensively investigated (Tillie, 2018). Implementation of synergetic thinking should now be a priority, and it is necessary that the integration and sustainability of urban flow systems should shape the city. Consciously, and not as an invisible unexpected add-on to our cities. Integrated urban flows should be designed to lead to attractive places, in which the brilliance of the systems has become visible, can be witnessed and experienced by residents, and where new resources are celebrated.

\section{Thinking in Nexuses}

So far, the majority of academic work has been oriented towards quantification of flows, assessment tools, and determining what one flow needs from another to operate? Do we have enough water for bioenergy, how much electricity is needed for desalination? These types of questions are mainstream, often focusing on only one urban flow. In recent decades the energywater nexus has received the majority of the attention, as can be witnessed by a broad range, but not exhaustive, of literature shown here (Bauer, Philbrick, \& Vallario, 2014; Byers, Hall, \& Amezaga, 2014; Connor \& Koncagül, 2014; Cooley \& Wilkinson, 2012; Davies, Kyle, \& Edmonds, 2013; Gleick, 1994; Halstead, Kober, \& van der Zwaan, 2014; Henthorne, 2009; Inhaber, 2004; Kohli \& Frenken, 2011; Koulouri \& Moccia, 2014; Lavelle \& Grose, 2013; Macknick, Newmark, Heath, \& Hallett, 2012; Macknick, Sattler, Averyt, Clemmer, \& Rogers, 2012; Mielke, Diaz Anadon, \& Narayanamurti, 2010; Mitra \& Bhattacharya, 2012; Plappaly \& Lienhard, 2012; Radcliffe, 2018; Rodriguez, Delgado, DeLaquil, \& Sohns, 2013; Sanders \& Webber, 2013; Spang, Moomaw, Gallagher, Kirshen, \& Marks, 2014; Stiegel et al., 2009; US

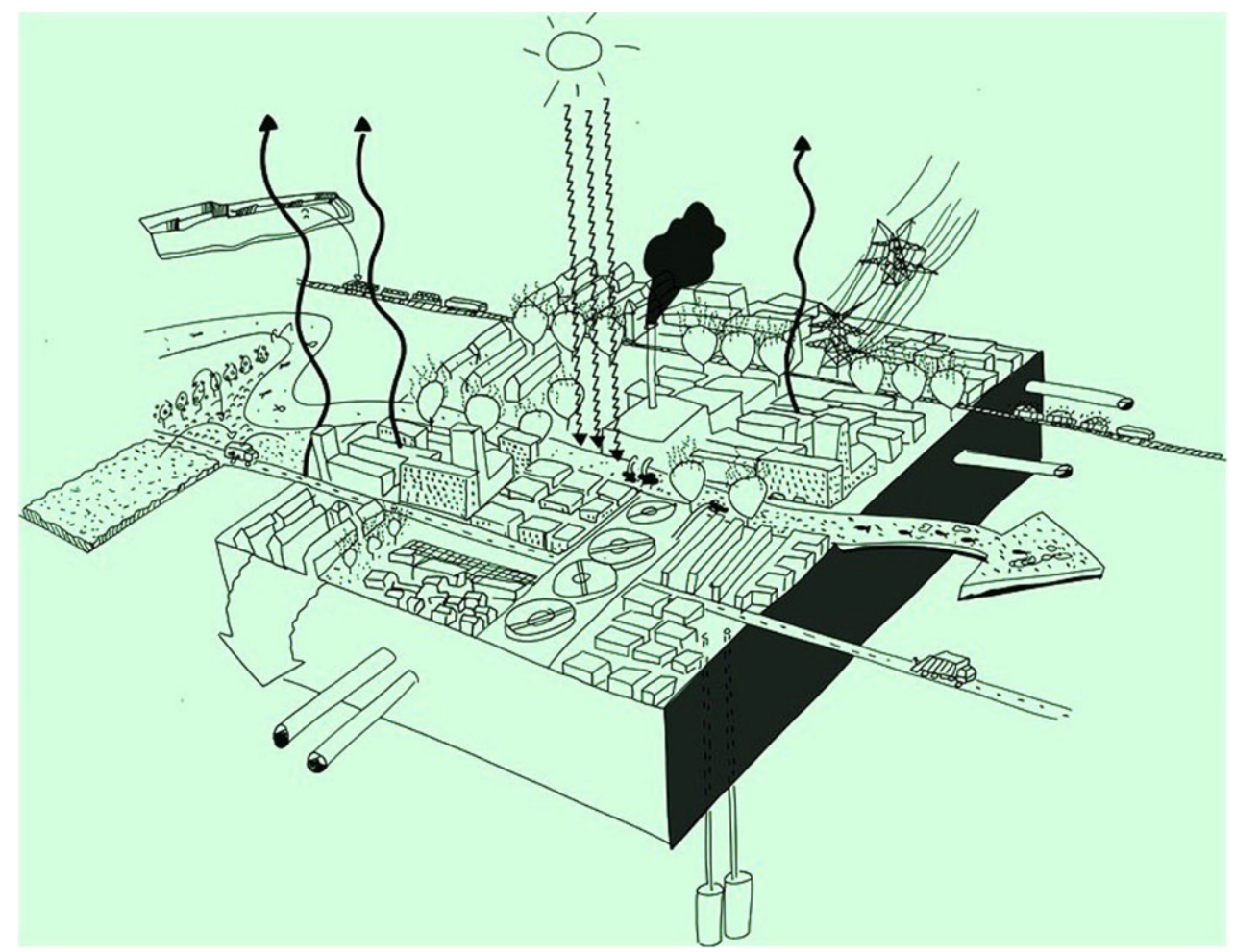

Figure 3. Urban metabolism model. Source: Dirk Sijmons/Jutta Raith (Gemeente Rotterdam et al., 2014). 
Department of Energy, 2006; Wang, 2013; Water in the West, 2013; Webber, 2008; World Energy Council, 2010).

The nexus of water and food has been investigated in the agricultural literature, while the energy-food nexus is less well researched (ISIS, 2013; WISIONS, 2007) and very few linkages are made between food, energy and water and ecosystems (UNECE \& KTH, 2014).

Only recently integrated thinking about water, energy and food emerged as the food-energy-water nexus (Barrett, 2014; Bazilian et al., 2011; Bizikova, Roy, Swanson, Venema, \& McCandless, 2013; BMU, 2012; Ferroukhi et al., 2015; Flammini, Puri, Pluschke, \& Dubois, 2014; Granit et al., 2013; Hanlon et al., 2013; Hoff, 2011; Mohtar \& Daher, 2012, 2013; Shannak, Mabrey, \& Vittorio, 2018; SEI, 2011; World Economic Forum, 2011). Especially after the Bonn2011 meeting the research agenda sparked, and new investigations occurred and reached the academic journals. The majority of these research outputs are focus on quantifying the flows, developing assessment tools and/or aim to define the relationship quantitively between two or more of the flows. The implications of different sizes, relationships and amounts of flows for the city are less well researched. A design-led approach is rare, and this may be one of the reasons it is very difficult to amend the systems of water, energy and food to establish more integrated, sustainable and resilient urban systems (GIZ \& ICLEI, 2014).

\section{The Thematic Issue}

The focus on quantification of urban flows is, on the one hand, needed to understand what we are talking in the first place. It does matter with how much water we have to deal in the city, how much energy is required, or how much food must be grown to feed the population. However, on the other hand understand quantity only is not enough. Reduced amounts of flows must also be integrated in the spatial context of the city, towns and landscape. Therefore, this thematic issue of Urban Planning features articles that illuminate the possibilities of design-led approaches to inclusion of urban flows in the city. To set the scene, Roggema (2019) starts with sketching the current context of disruptive developments, which influence the context and the spatial options in the city. The space available and the amounts of networks for unexpected change determines the adaptivity of systems, and the possibility to introduce counterintuitive solutions. Yan and Roggema (2019) focus on design-led approaches for the food-energy-water nexus, and integrate spatial, governance and appraisal aspects of the nexus. Han and Keeffe (2019) focus on a very interesting flow, the move of urban forests through the city. In their article, Galan and Perrotti (2019) highlight the opportunities for sustainable metabolism at the regional level. The way people can be involved and given a larger stake in their consumption of basic flows is the subject in McLean and Roggema (2019), while a different perspective on governance to improve urban metabolism, increasing accountability in strategic planning, is given in Zengerling (2019).

This thematic issue brings together insights and perspectives on the "city of flows", an orientation on the possibilities to change the spatial design for the city as a result of choices made for flow systems. This design-led thinking is, so-far, underestimated in realizing a resilient system of flows in urban environments. Even in acquiring academic outputs for this thematic issue, it proved to be not easy to collect an abundant number of articles. There is still a long way to go, especially because the quantification, assessing and defining of urban flows will not easily lead to implementation, and hence to a more resilient and sustainable city. The way design approaches can visualize solutions and propose unprecedented and innovative solutions is unmet by most current published research.

\section{Conclusion: Future?}

State of the art literature shows that most research focuses recently on the food-energy-water nexus. While in building research materials form a substantial body of knowledge, the use of waste and materials at the urban design level is not very common. Therefore, it is suggested to add and integrate these flows to the model. Finally, the rapid development of data collection, analysis, data-driven design and the use of data in planning our cities (Smart Cities), would justify starting thinking about integrating data in the urban metabolism model, despite data being often non-physical.

\section{References}

Barrett, K. (2014). The water-energy-food nexus: Interlinked solutions for interlinked challenges. Ecosystem Marketplace. Retrieved from www.ecosystem marketplace.com/articles/the-water-energy-food-ne xus-interlinked-solutions-for-interlinked-challenges

Bauer, D., Philbrick, M., \& Vallario, B. (2014). The waterenergy nexus: Challenges and opportunities. Washington, DC: US DOE.

Bazilian, M., Rogner, H., Howells, M., Hermann, S., Arent, D., Gielen, D., . . . Yumkella, K. K. (2011). Considering the energy, water and food nexus: Towards an integrated modelling approach. Energy Policy, 39(12), 7896-7906. https://doi.org/10.1016/ j.enpol.2011.09.039

Bizikova, L., Roy, D., Swanson, D., Venema, H. D., \& McCandless, M. (2013). The water-energy-food security nexus: Towards a practical planning and decision-support framework for landscape investment and risk management. Winnipeg: International Institute for Sustainable Development. Retrieved from www.iisd.org/pdf/2013/wef_nexus_2013.pdf

BMU. (2012). Bonn 2011 conference: The water, energy and food security nexus. Solutions for a green economy. Policy recommendations. Bonn: German 
Federal Ministry for the Environment, Nature Conservation and Nuclear Safety. Retrieved from www. water-energy-food.org/fileadmin/user_upload/files/ documents/bonn2011_policyrecommendations.pdf

Brugmans, G., \& Strien, J. (Eds.). (2014). IABR 2014: Urban by nature. Amsterdam: Idea Books.

Byers, E. A., Hall, J. W., \& Amezaga, J. M. (2014). Electricity generation and cooling water use: UK pathways to 2050. Global Environmental Change, 25, 16-30. Retrieved from www.sciencedirect.com/ science/article/pii/S0959378014000089

Connor, R., \& Koncagül, E. (2014). The United Nations world water development report 2014: Water and energy. Paris: UNESCO.

Cooley, H., \& Wilkinson, R. (2012). Implications of future water supply and sources for energy demands. Alexandria: WaterReuse Foundation. Retrieved from www.pacinst.org/wp-content/uploads/ 2013/02/report19.pdf

Davies, E. G. R., Kyle, P., \& Edmonds, J. A. (2013). An integrated assessment of global and regional water demands for electricity generation to 2095. Advances in Water Resources, 52, 296-313. https://doi.org/10.1016/j.advwatres.2012.11.020

Ferroukhi, R., Nagpal, D., Lopez-Peña, A., Hodges, T., Mohtar, R. H., Daher, B., . . Keulertz, M. (2015). Renewable energy in the water, energy \& food nexus. Abu Dhabi: IRENA.

Flammini, A., Puri, M., Pluschke, L., \& Dubois, O. (2014). Walking the nexus talk: Assessing the water-energyfood nexus in the context of the sustainable energy for all initiative (Environment and natural resources Working Paper no 58). Rome: FAO. Retrieved from www.fao.org/3/a-i3959e.pdf

Galan, J., \& Perrotti, D. (2019). Incorporating metabolic thinking into regional planning: The case of the Sierra Calderona strategic plan. Urban Planning, 4(1), 152-171.

Gemeente Rotterdam, IABR, FABRIC, JCFO, \& TNO. (2014). Urban metabolism. Sustainable development of Rotterdam. Rotterdam: IABR.

GIZ, \& ICLEI. (2014). Operationalizing the urban nexus: Towards resource efficient and integrated cities and metropolitan regions. Eschborn: GIZ.

Gleick, P. H. (1994). Water and energy. Annual Review of Energy and the Environment, 19(1), 267-299.

Granit, J., Rosemarin, A., Hoff, H., Karlberg, L., Fogde, M., \& Kuylenstierna, J. L. (2013). Unpacking the waterenergy-food nexus: Tools for assessment and cooperation along a continuum. In A. Jägerskog, T. J. Clausen, K. Lexén, \& T. Holmgren (Eds.), Cooperation for a water wise world: Partnerships for sustainable development. Report no 32 (pp. 45-50). Stockholm: Stockholm International Water Institute.

Halstead, M. I., Kober, T., \& van der Zwaan, B. (2014). Understanding the energy-water nexus (ECN-E--14046 Report). Petten: Energy Research Centre of the Netherlands. Retrieved from ftp.ecn.nl/pub/www/ library/report/2014/e14046.pdf

Han, Q., \& Keeffe, G. (2019). Mapping the flow of forest migration through the city under climate change. Urban Planning, 4(1), 139-151.

Hanlon, P., Madel, R., Olson-Sawyer, K., Rabin, K., Rose, J., Demaline, K., \& Sweetman, K. (2013). Food, water and energy: Know the nexus. New York, NY: GRACE Communications Foundation. Retrieved from www. gracelinks.org/media/pdf/knowthenexus_final.pdf

Henthorne, L. (2009). Desalination: A critical element of water solutions for the 21st century. Drinking water-sources, sanitation and safeguarding. Stockholm: Swedish Research Council Formas.

Hoff, H. (2011). Understanding the nexus. Paper presented at the Bonn 2011 conference, The Water, Energy and Food Security Nexus, Stockholm.

Inhaber, H. (2004). Water use in renewable and conventional electricity production. Energy Sources A, 26, 309-322.

ISIS. (2013). Japanese farmers producing crops and solar energy simultaneously. Institute of Science in Society. Retrieved from www.i-sis.org.uk/Japanese _Farmers_Producing_Crops_and_Solar_Energy.php

Kohli, A., \& Frenken, K. (2011). Cooling water for energy generation and its impact on national-level water statistics. Rome: FAO.

Koulouri, A., \& Moccia, J. (2014). Saving water with wind energy. Brussels: European Wind Energy Association. Retrieved from www.ewea.org/fileadmin/ files/library/publications/reports/Saving_water_with _wind_energy.pdf

Kristinsson, J. (2012). Integrated sustainable design. Delft: Delft Digital Press.

Lavelle, M., \& Grose, T. (2013). Water demand for energy to double by 2035. National Geographic. Retrieved from news.nationalgeographic.com/news/ energy/2013/01/130130-water-demand-for-energyto-double-by-2035

Macknick, J., Sattler, S., Averyt, K., Clemmer, S., \& Rogers, J. (2012). The water implications of generating electricity: Water use across the United States based on different electricity pathways through 2050. Environmental Research Letters, 7. https://doi.org/ 10.1088/1748-9326/7/4/045803

Macknick, J., Newmark, R., Heath, G., \& Hallett, K. C. (2012). Operational water consumption and withdrawal factors for electricity generating technologies: A review of existing literature. Environmental Research Letters, 7. https://doi.org/10.1088/17489326/7/4/045802

McLean, L., \& Roggema, R. (2019). Planning for a prosumer future: The case of Central Park, Sydney. Urban Planning, 4(1), 172-186.

Mielke, E., Diaz Anadon, L., \& Narayanamurti, V. (2010). Water consumption of energy resource extraction, processing and conversion. Cambridge, MA: Belfer Center for International Affairs, Harvard Kennedy School of Government. 
Mitra, B. K., \& Bhattacharya, A. (2012). Long term electricity scenario and water use: A case study on India (IGES Policy Brief). Kanagawa: Institute for Global Environmental Strategies. Retrieved from http://pub.iges.or.jp/modules/envirolib/view.php?doc id $=4089$

Mohtar, R., \& Daher, B. (2012). Water, energy, and food: The ultimate nexus. In D. R. Heldman, \& C. I. Moraru (Eds.), Encyclopedia of agricultural, food, and biological engineering (2nd ed.). Abingdon-onThames: Taylor \& Francis. Retrieved from wefnexus tool.org/docs/water,\%20energy,\%20and\%20food_ the\%20ultimate\%20nexus\%20(mohtar,\%20daher,\%2 02012).pdf

Mohtar, R., \& Daher, B. (2013). Water-energy-food nexus. A basis for strategic resource planning. Paper presented at a Workshop on Moving Ahead to Implement the Nexus approach, Lessons Learnt and Discussion of Next Steps Regarding Integrated Assessment of Water-Energy-Food Needs in a Climate Change Context, Rome.

Newman, P. W. G. (1999). Sustainability and cities: Extending the metabolism model. Landscape and Urban Planning, 44(4), 219-226. https://doi.org/ 10.1016/S0169-2046(99)00009-2

Plappaly, A., \& Lienhard, V. J. (2012). Energy requirements for water production, treatment, end use, reclamation, and disposal. Renewable and Sustainable Energy Reviews, 16(7), 4818-4848. http://dx.doi.org/10.1016/j.rser.2012.05.022

Radcliffe, J. C. (2018). The water energy nexus in Australia: The outcome of two crises. Water-Energy Nexus, 1(2018), 66-85.

Rodriguez, D. J., Delgado, A., DeLaquil, P., \& Sohns, A. (2013). Thirsty energy. New York, NY: World Bank. Retrieved from documents.worldbank.org/curated/ en/835051468168842442/pdf/789230REPLACEMOst y0Energy0204014web.pdf

Roggema, R. (2019). Design for disruption: Creating antifragile urban delta landscapes. Urban Planning, 4(1), 113-122.

Sanders, K., \& Webber, M. (2013). The energy-water nexus: Managing water in an energy-constrained world. Earth Magazine. Retrieved from www.earth magazine.org/article/energy-water-nexus-managing -water-energy-constrained-world

SEI. (2011). Understanding the nexus. Paper presented at the Bonn 2011 conference, The Water, Energy and Food Security Nexus, Stockholm.

Shannak, S., Mabrey, D., \& Vittorio, M. (2018). Moving from theory to practice in the water-energyfood nexus: An evaluation of existing models and frameworks. Water-Energy Nexus, 1(2018), 17-25. https://doi.org/10.1016/j.wen.2018.04.001

Spang, E. S., Moomaw, W. R., Gallagher, K. S., Kirshen, P. H., \& Marks, D. H. (2014). The water consumption of energy production: An international comparison. Environmental Research Letters, 9(10). https://doi.org/10.1088/1748-9326/9/10/105002

Stiegel, G. J., McNemar, A., Nemeth, M., Schimmoller, B., Murphy, J., \& Manfredo, L. (2009). Estimating fresh water needs to meet future thermoelectric generation requirements. Pittsburgh: NETL.

Tillie, N. (2018). Synergetic urban landscape planning in Rotterdam: Liveable low-carbon cities (Unpublished Doctoral dissertation). Delft University of Technology, Delft.

Tomásek, W. (1979). Die Stadt als Oekosystem; Überlegungen zum Vorentwurf Landschaftsplan Köln [The city as ecosystem. Considerations about the scheme of the landscape design in Cologne]. Landschaft+Stadt, 11, 51-60.

UNECE, \& KTH. (2014). Water-food-energy-ecosystems nexus: Reconciling different uses in transboundary river basins. Paper presented at the UNECE Water Convention. Retrieved from www.unece.org/file admin/DAM/env/documents/2014/WAT/09Sept_8-9 _Geneva/Methodology_1Sept2014_clean_forWeb.pdf

US Department of Energy. (2006). Energy demands on water resources: Report to Congress on the Interdependency of energy and water. Washington, DC: DOE.

Van Leeuwen, C. G. (1981). Ecologie en Natuurtechniek (3-5) [Ecology and nature technology]. Tijdschrift Koninklijke Nederlandse Heidemaatschappij, 92, 7-8.

Van Timmeren, A., \& Henriquez, L. (2015). Ubikquity \& the illuminated city. From smart to intelligent urban environments. Delft: TU Delft.

Wang, R. (2013). Water-energy nexus: A critical review paper. New Haven, CT: Yale School of Forestry and Environmental Studies.

Water in the West. (2013). Water and energy nexus: A literature review. Water in the West. Retrieved from waterinthewest.stanford.edu/sites/default/files/ Water-Energy_Lit_Review.pdf

Webber, M. (2008). Water versus energy. Scientific American. Retrieved from www.scientificamerican. com/article/the-future-of-fuel

WISIONS. (2007). Renewable energy in the food supply chain. Wuppertal: WISIONS. Retrieved from www. wisions.net/files/uploads/PREP_09_Food_Supply.pdf

Wolman, A. (1965). The metabolism of cities. Scientific American, 213, 179-190.

World Economic Forum. (2011). Water security: The water-food-energy-climate nexus. Geneva: WEF.

World Energy Council. (2010). Water for energy. London: World Energy Council.

Yan, W., \& Roggema, R. (2019). Developing a design-led approach for the food-energy-water nexus in cities. Urban Planning, 4(1), 123-138.

Zengerling, C. (2019). Governing the city of flows: How urban metabolism approaches may strengthen accountability in strategic planning. Urban Planning, 4(1), 187-189. 


\section{About the Author}

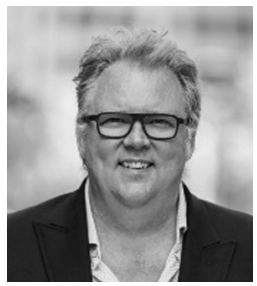

Rob Roggema (PhD) is Professor of Sustainable Spatial Transformations at the Knowledge Centre Noorderruimte, Hanze University Groningen. He is a landscape architect and an internationally renowned design-expert on sustainable urbanism, climate adaptation, energy landscapes and urban agriculture. He has previously held positions at universities in the Netherlands and Australia, State and Municipal governments and design consultancies. Rob developed the Swarm Planning concept, a dynamic way of planning the city for future adaptation to the impacts of climate change.le of urban planning and architecture in the daily lives of asylum seekers and their future trajectories. 